\title{
Discounting and the Green Transition: District Heating in Denmark
}

\author{
Mark C. Freeman ${ }^{1 a}$, Frikk Nesje ${ }^{b}$, Daniel Møller Sneum ${ }^{c}$, Emilie Rosenlund Soysal ${ }^{d}$ \\ 1a University of York Management School. \\ b University of Copenhagen, Department of Economic. \\ c Technical University of Denmark, Management \\ d Potsdam Institute for Climate Impact Research. Alphabetical ordering of authors. \\ Author for correspondence: Mark Freeman, Mark.Freeman@York.ac.uk
}

\begin{abstract}
Taking Aalborg as the basis for a case study, we consider the discount rates, annuity rates and costs of capital that were used in recent socio-economic and financial Net Present Value (NPV) analyses of a proposed geothermal district heating plant. While the core NPV analysis applied a real social discount rate of 4 percent, in keeping with Danish government guidance, emissions and electricity prices were based on costs of capital that differed from this rate, as did the annuity rate applied in the financial analysis of the project. While the different rates are carefully justified in each setting, we question whether there is consistency in the approach taken to intergenerational welfare across different steps of the analysis. The use of high corporate rates in some contexts potentially makes it more difficult for Green Transition projects to meet the legal requirement of being evaluated as socio-economically optimal.
\end{abstract}

KEYWORDS: Geothermal, District Heating, Social Discounting, Net Present Value, Socio-Economic Analysis

\section{INTRODUCTION}

The Green Transition in domestic heating requires governments, energy companies and other organisations to provide substantial up-front investment in new technologies and infrastructure. This investment is subsequently repaid over long time-periods through revenue generation from household energy bills and lower greenhouse gas emissions. Determining the socio-economic and financial cases for the Green Transition therefore requires us to balance the initial investment costs against the long-term financial and environmental benefits through net present value (NPV) analyses. The discount rate is the variable that balances the present value against the future value within these calculations.

In this chapter, we describe how Danish energy authorities apply social discount rates within their domestic policy context. We frame our discussion around a single concrete project proposal on geothermal energy in Denmark: a 100 MW geothermal plant based in Aalborg. By examining the up-front costs, expected operational costs, predicted carbon savings, and the uncertainties surrounding the eventual success of the project, we describe how Danish energy authorities might best set a discount rate in order to undertake a socio-economic appraisal of this proposal. From this, we draw wider lessons on how discounting under the Green Transition can be best undertaken within the Danish energy regulation context.

This issue is of pressing concern for energy regulation and the Green Transition. Because of the very long time-periods over which carbon dioxide remains in the atmosphere, ${ }^{2}$ the overall benefits from Green Transition projects extend over many centuries. As a consequence, and as highlighted by the Stern Review and subsequent responses to it, the calculated NPV from greenhouse gas emissions reduction projects are generally highly sensitive to the discount rate employed. ${ }^{3}$ Usually, if the discount rate applied is "too high" within the regulatory framework, then this will lead to the rejection of projects that would aid in the Green Transition; meaning that appraisers have also failed in their legal obligation to invest in projects that are socio-economically optimal. If

\footnotetext{
2 Nasa, 2019. The Atmosphere: Getting a Handle on Carbon Dioxide.

3 See, for example, Stern, N. (2007), The Stern Review on the Economics of Climate Change, Cambridge University Press, Cambridge; Stern, N., (2008), "The economics of climate change", American Economic Review: Papers \& Proceedings, 98(2), 1-37; and Nordhaus, W.D. (2007), "A review of the Stern Review on the Economics of Climate Change", Journal of Economic Literature, 45, 686-702.
} 
the "wrong" annuity rate is applied within the financial analysis of a project, the consequence is that domestic energy prices will be incorrectly set.

Because of the importance of accurately estimating the discount rate in these contexts and the complexities that arise when trying to do so, detailed academic literature has been developed in recent years. In parallel with this, a wide range of international governmental bodies have issued policy guidance on the appropriate social discount rate to apply to very long term environmental projects. It is essential that energy regulation within Denmark adopts best available practice in this area as it moves through a Green Transition.

The chapter proceeds as follows. In Section 2, we provide a brief background to the Aalborg project, before describing in Section 3 how the costs of the project, and those of the woodchip combined heat and power plant against which it was compared, are calculated. In Section 4 , we explain why a 4 percent real social discount rate was used in the socio-economic analysis of the project and compare this to rates that are used by public bodies in other international contexts. Specifically, we show that for any "reasonable" choice of discount rate, the geothermal project appears to be of greater socio-economic value than the woodchip plant alternative.

In Section 5, we return to how the emissions and electricity costs, which form a basis for the NPV analysis, are estimated. We focus on the fact that each component is calculated using independent models that each include their own assessment of an appropriate cost of capital. These usually differ from the 4 percent social discount rate that is used in the core NPV calculation. We also observe that in the financial analysis of the project, initial investment costs are recouped through household energy bills, based on a calculation that applies an annuity rate that also differs from the discount rates applied in the socio-economic analysis.

Section 6 provides the discussion and conclusion. Our central observation is that there is no explicit, overarching, economic framework that jointly considers the different discount rates, annuity rates and costs of capital that are used in the separate calculations that form inputs to the overall socio-economic and financial analyses of the project. As a consequence, we cannot be certain whether the different methods can co-exist within a unified economic and ethical framework, or whether they instead reflect more fundamental inconsistencies in approaches to questions of intertemporal welfare. Even in the analysis of this relatively simple project, a number of important questions are raised about how discount rates, annuity rates and costs of capital, should be consistently estimated in a Danish energy regulation context and we believe that these questions require further exploration.

\section{BACKGROUND TO GEOTHERMAL DISTRICT HEATING AND THE AALBORG PROJECT}

While the origins of geothermal energy for heating date back to the hypocausts (central heating under the floor) of ancient Rome, its potential to help service a carbon-neutral future are vast. Estimates suggest that it could provide enough energy to meet the consumption demands of the entire world for six million years, with 340 exajoules (EJ) per year in Europe alone and meet 30\% of Danish district heating needs. ${ }^{4}$ Modern geothermal district heating is typically the process of injecting a fluid through a well, where it extracts underground heat from a reservoir. The fluid is pumped to the surface where heat is extracted. Temperatures vary depending on depth and the availability of geothermal heat. In the Swedish city of Lund, $25^{\circ} \mathrm{C}$ water is extracted and subsequently utilised in heat pumps to generate higher temperature water for the district heating grid. $5^{5}$ The same principle applies in the Danish town of Thisted, but with a temperature of $43^{\circ} \mathrm{C} .6^{6}$

In 2020, the Danish Energy Agency evaluated the regulatory framework for geothermal energy for district heating in Denmark. ${ }^{7}$ Contrary to the specific Aalborg case, the Danish Energy Agency concluded that, under the current regulatory framework, geothermal energy is not a competitive technology for district heating supply. This is mainly due to risks and high investment costs. Risks include the geological conditions that "can vary substantially within a few kilometres in the underground". ${ }^{8}$ Investment costs are high because geothermal equipment must be able to withstand harsh conditions and the process can lead to, for example, the fouling of filters and corrosive substances. ${ }^{9}$

\subsection{GEOTHERMAL DISTRICT HEATING IN AALBORG}

Aalborg, the fourth-largest city in Denmark with over 100,000 inhabitants, ${ }^{10}$ is mainly supplied with district heating from the combined heat and power (CHP) plant Nordjyllandsværket ('the North Jutland plant'), the Reno-Nord waste incineration plant and excess industrial heat from the Aalborg Portland cement factory: 3,871 terajoules (TJ), $1,543 \mathrm{TJ}$ and 1,166 TJ, respectively, in 2018. ${ }^{11}$ In 2015, the Aalborg Municipality bought Nordjyllandsværket and in 2017 explored a strategy to achieve fossil-free heat production by 2028 , by which date the Nordjyllandsværk will reach its end of life. ${ }^{12}$ In 2019, a project proposal was published on the deployment of approximately 10 geothermal wells with an aggregate heat production capacity of $100 \mathrm{MW}$ in Aalborg; hereafter referred to as "the geothermal plant". ${ }^{13}$

\footnotetext{
4 Werner, S. (2017). International review of district heating and cooling, Energy, 137, p.206.

5 Ibid p.210.

6 Danish Geothermal District Heating. Drejebog om geotermi, 2014, p. 7.

7 Danish Energy Agency, 2020. Geotermianalyse.

8 Danish Energy Agency, 2020. Geotermianalyse, p.7.

9 Werner, S. (2017). International review of district heating and cooling, Energy, 137, p. 207.

10 Danmarks Statistik, 2020. Folketal 1. januar efter byområder, landdistrikter, alder og køn.

11 Aalborg Forsyning, 2019. Årsrapport 2019: Varme, p.14.

12 Miljø -og Energiplanlægningen, 2015. Notat: Strategi for fossilfri varmeproduktion, p.2.

13 Cowi, 2019. Projektforslag: Aalborg Kommune, p.6.
} 
Aalborg Forsyning, a utility company, will own and operate the plant, based on a "turnkey", full package, solution. Before the transfer of ownership, the supplier will be responsible for the preliminary exploration, design, construction and commissioning. ${ }^{14}$ When ownership of the geothermal plant is transferred, so is the risk, barring the contractual guarantees. At the same time as this study went to press, the geothermal project was put on hold due to a lack of bids for the tender. ${ }^{15}$

Legislation requires the municipal council, as the governing authority, to choose the option with the best socio-economic outcome. To determine whether the geothermal plant met this legal obligation, an alternative scenario was established, consisting of a $100 \mathrm{MW}$ (thermal capacity) woodchip-based CHP plant. According to economic analysis, which we will describe in Section 3, the geothermal solution saves 74 million EUR (551 million Danish Krone) compared to the woodchip CHP plant in present value terms over its lifetime, and the geothermal plant is therefore the socio-economically preferred option.

While this conclusion - that the geothermal plant in Aalborg is economically optimal - stands in contrast to the national-scale analysis undertaken by the Danish Energy Agency, they may still nevertheless both be correct. One reason for the difference is the choice of alternative technologies used in the respective studies: the national study applies biomass boilers and sea water-based heat pumps, while the Aalborg case compares against a woodchip CHP plant. A second reason is that local geothermal conditions in Aalborg differ from the national average.

\section{COST-BENEFIT ESTIMATES FOR THE SOCIO-ECONOMIC NPV}

We now turn to the socio-economic analysis of the geothermal and woodchip CHP plants that the Aalborg municipal council considered when determining the best socio-economic outcome. The analysis follows the guidelines of the Danish Energy Agency and is based on an NPV analysis of the economic costs and benefits over a period of 20 years, discounted at a real social discount rate of 4 percent; an issue we return to in Section 4. In this section, we concentrate on the cost estimates, which are categorized into six parts: investments, terminal 'scrap' value, operations \& maintenance (O\&M), energy consumption, environmental damages, and deadweight cost from distortionary taxes.

Our assumptions on technical performance, investments and O\&M costs follow the proposal from Aalborg Forsyning. All other cost estimates are calculated according to the guidelines for socio-economic analysis set by the Danish Energy Agency. ${ }^{16}$ Among other data needed for the analysis, the Agency provides price estimates for electricity, fuel and various emissions and we will return to a discussion of the origin of these prices in Section 5 .

\subsection{CONVERSION FROM FACTOR PRICES TO SOCIO-ECONOMIC VALUES}

Fundamentally, there are two types of prices used in the calculations: socio-economic and private economic. While emission damages (besides $\mathrm{CO}_{2}$ emissions) and deadweight costs are priced in terms of their socio-economic value, the costs of investments, terminal value, $\mathrm{O} \& \mathrm{M}$, energy consumption and $\mathrm{CO}_{2}$ emissions are given in private economic factor prices; i.e. market prices without value added tax and excise duties. The socio-economic cost analysis needs socio-economic prices, and these are better reflected in consumers' willingness to pay, including indirect taxation. For this reason, factor prices are multiplied by a fixed conversion factor. ${ }^{17}$ The Danish Ministry of Finance estimates the conversion factor as $1.325,18$ reflecting the level of indirect taxation.

From the point of view of the government, the conversion factor reflects the fact that public spending reduces the disposable income of consumers. This leads to reduced private consumption and thus lower revenue from indirect taxes. ${ }^{19}$ The 'backflow' loss of tax revenue is an additional cost in the fiscal budget, and the conversion factor of 1.325 corresponds to a tax backflow of 24.5 percent.

\subsection{THE GEOTHERMAL PLANT COSTS AND BENEFITS}

According to the project proposal, ${ }^{20}$ investment in the ten geothermal wells is undertaken during a 4-year period, and the plant is operational with full capacity in 2028. During the operational period there are both fixed and variable O\&M costs. The lifetime of each geothermal well is set to 25 years, implying a terminal value at the end of the 20 -year calculation window. The geothermal plant runs on electricity, hence the energy consumption costs consist of the electricity price and the cost of electricity transmission and distribution. The price projections for average electricity are provided by the Danish Energy Agency and we discuss these in Section 5. The average electricity price is adjusted by a factor of 0.83 to reflect the possibility of shifting operation to periods with low-cost electricity. Figure 1 illustrates the cost structure of the geothermal plant.

\subsubsection{EMISSION DAMAGES}

The socio-economic cost-benefit analysis accounts for damages caused by pollutants emitted during the production of the consumed electricity. According to the guidelines, the pollutants considered are carbon dioxide $\left(\mathrm{CO}_{2}\right)$, methane $\left(\mathrm{CH}_{4}\right)$, laughing gas $\left(\mathrm{N}_{2} \mathrm{O}\right)$, sulphur dioxide $\left(\mathrm{SO}_{2}\right)$, nitrogen oxides $\left(\mathrm{NO}_{\mathrm{x}}\right)$ and particulates $(\mathrm{PM} 2.5)$. As there is

\footnotetext{
14 Aalborg Forsyning, 2019. Udbud af Geotermi.

15 Aalborg Forsyning, 2020. Udbud af geotermianlæg.

16 Energistyrelsen, 2018. Vejledning i Samfundsøkonomiske Analyser på Energiområdet.

17 See section 3.1.4 in Energistyrelsen, 2018.Vejledning i Samfundsøkonomiske Analyser på Energiområdet.

18 Finansministeriet, 2019. Dokumentationsnotat om opgørelse af nettoafgiftsfaktoren.

19 Fosgerau, M., \& Pilegaard, N. (2015). Nettoafgiftsfaktoren. DTU Transport. DTU Transport. Notat, Vol.. 14

${ }^{20}$ Cowi, 2019. Etablering af 100MW geotermisk anlæg - Projektforslag.
} 


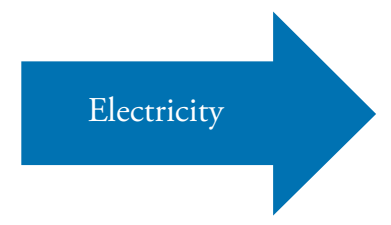

- Energy costs (electricity)

- Emission damages (reference electricity)

- Tax distortion $(-10 \%$ of electricity consumption tax)

\section{NEW}

GEOTHERMAL PLANT

- Investments

- Terminal value

- O\&M

\section{FIGURE 1. GEOTHERMAL PLANT - OVERVIEW OF THE SOURCES OF SOCIO-ECONOMIC COSTS. SOURCE: OWN ILLUSTRATION.}

no electricity production in the proposed plant, the electricity that the plant uses is assumed to have emission characteristics in line with average electricity in the Danish power system, for which the Danish Energy Agency provides emission projections. The costs of $\mathrm{CO}_{2}$ emissions are assumed to be included in the electricity price, although the electricity price does not include the costs of damages from other emissions created during its production. $\mathrm{CH}_{4}$ and $\mathrm{N}_{2} \mathrm{O}$ are greenhouse gasses, hence emissions of these pollutants are first transformed into a $\mathrm{CO}_{2}$-equivalent. This is then valued using the projected price for $\mathrm{CO}_{2}$ for emissions outside the EU Emissions Trading System (ETS). $\mathrm{SO}_{2}, \mathrm{NO}_{\mathrm{x}}$, and PM2.5 are priced according to their estimated marginal damages, published by the Danish Ministry of Environment and Food. ${ }^{21}$

\subsubsection{DEADWEIGHT COSTS}

The final element of the socio-economic costs and benefits is the deadweight cost caused by distortionary taxes. There are a number of energy sector specific taxes levied on the consumption of energy products, and while these are not socio-economic costs, new investments may lead to changes in the tax revenue. A positive change to the fiscal balance implies less taxation of other activities in Danish society, which contributes positively to the economy overall. Likewise, a negative change implies more taxation of other activities, and hence a deadweight cost. The Danish Ministry of Finance sets the deadweight cost to $10 \%$ of the changes in tax revenues. In the geothermal plant proposal, the tax paid on consumed electricity generates a tax revenue, ${ }^{22}$ providing a benefit for the economy due to less distortionary taxes elsewhere.

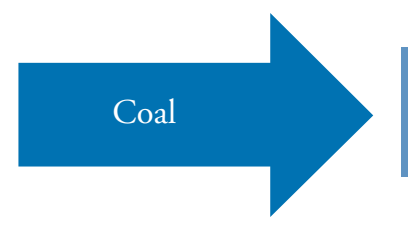

- Energy costs (coal)

- Emission damages

- Tax distortion $(-10 \%$ of coal tax $)$

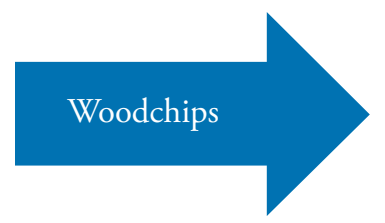

- Energy costs (woodchips)

- Emission damages

- Tax distortion $(-10 \%$ of woodchip tax)

\section{EXISTING}

\section{COAL CHP}

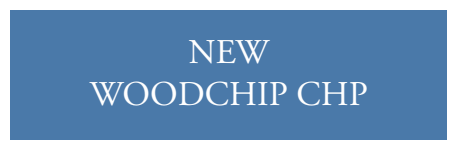

- Investments

- Scrap value

- O\&M
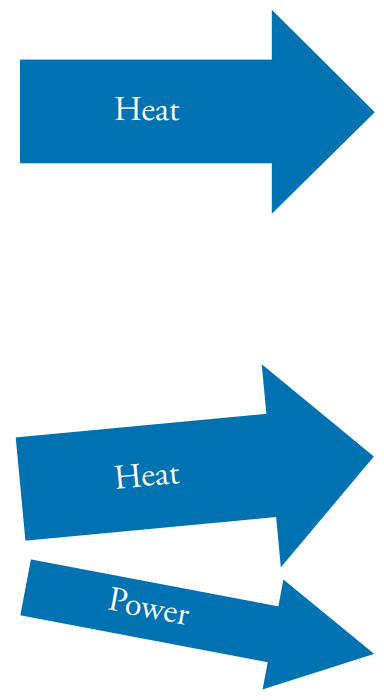

- Negative energy costs (electricity)

- Negative emission damages (reference electricity)

FIGURE 2. REFERENCE SCENARIO - OVERVIEW OF THE SOURCES OF SOCIO-ECONOMIC COSTS. SOURCE: OWN ILLUSTRATION.

\footnotetext{
21 See section 6.2. in Energistyrelsen, 2019. Samfundsøkonomiske beregningsforudsætninger for energipriser og emissioner.

22 See section 3.1.5. in Energistyrelsen, 2018. Vejledning i samfundsøkonomiske analyser på energiområdet.
} 
The socio-economic NPV analysis does not include revenues from heat sales. This is because, in the financial analysis of the project, household heating bill revenues are adjusted to cover the costs of running the plant under the requirement that this project is undertaken on a notfor-profit basis.

\subsection{THE REFERENCE SCENARIO: WOODCHIP CHP PLANT}

In order to evaluate the socio-economic case for the geothermal plant against an alternative, a reference scenario was selected, and the costs for this are illustrated in Figure 2. The project proposal assumes that the existing coal plant covers the heat demand between 2024 and 2027. In 2027, the district heating company undertakes investment in a new woodchip CHP plant, which then takes over the heat supply from 2028.

The calculation of the socio-economic costs and benefits of the reference scenario is equivalent to that of the geothermal plant. A key difference, though, is that the woodchip plant produces both heat and power, and the latter can be sold in the electricity market, generating a stream of revenues. Hence, the energy consumption costs consist of the cost of coal and woodchips net of the revenue from electricity sales. Likewise, under the assumption that the produced electricity replaces reference electricity in the power system, the emission damages are calculated on the basis of the emissions from burning coal and woodchips, net of the emissions from the corresponding reference electricity. The guidelines set the $\mathrm{CO}_{2}$ emissions from burning woodchips to zero.
Consumption of woodchips and coal is subject to various taxes, leading to additional tax revenues. Hence, the fuel taxes constitute a socio-economic benefit, and the reduction in deadweight costs is set to $10 \%$ of the fuel tax collected.

\subsection{COMPARISON OF THE NET PRESENT VALUE OF COSTS}

Figure 3 compares the different components of the socio-economic NPV with a real discount rate of 4 percent applied. These relate to the costs of the projects, since the revenues from heat sales are not included. A lower value is therefore associated with a stronger socio-economic case. This graph shows that the geothermal project $(\mathrm{NPV}=2.09$ billion Danish Krone / 280.5 million EUR) is to be preferred to the woodchip CHP plant (NPV $=2.65$ billion Danish Krone / 355.7 million EUR).

The main difference comes from the higher energy and O\&M costs of the woodchip plant, while its investment costs are slightly lower. The geothermal plant has higher costs in the early years during which investment is undertaken, but lower running costs after 2027 compared to the woodchip CHP plant. In the reference scenario, the heat is supplied by the existing coal plant in the first four years and this appears to be a very inexpensive option. The additional heat delivery of the coal plant has a very high fuel efficiency, and causes no extra O\&M costs. The reference scenario would have been even less economical without the option to use cheap coal-fired heating in the early years. ${ }^{23}$

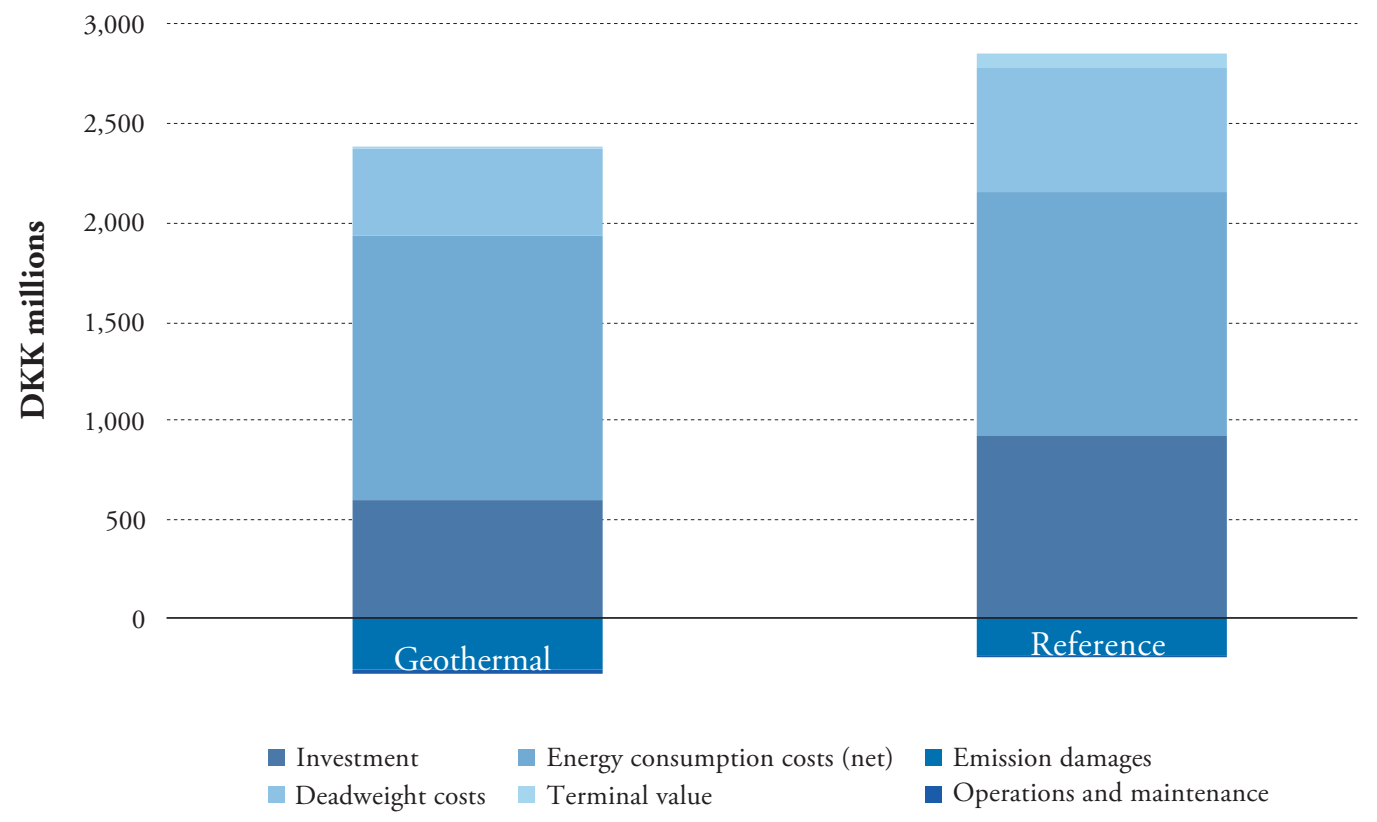

FIGURE 3. COMPARISON OF NET PRESENT VALUES OF COSTS (NOT REVENUES). SOURCE: OWN ILLUSTRATION.

\footnotetext{
23 According to the project owner, combining the geothermal plant with heat from the coal plant during the first few years would not be technically feasible because construction of the geothermal plant needs to be carried out over a number of years.
} 


\section{DISCOUNTING WITHIN THE SOCIO-ECONOMIC ANALYSIS}

\subsection{SOCIAL DISCOUNT RATE USED FOR CASH FLOW ANALYSIS AND THEIR BASIS IN GOVERNANCE GUIDANCE}

The NPV analysis presented in Figure 3 relies on the application of a real social discount rate of 4 percent to the costs that were identified with the geothermal and woodchip CHP plants. But choosing the right discount rate is of paramount importance to ensure a socially desirable portfolio of public-sector investments. The most recent guidelines for Denmark are from 2017 and are based on earlier Norwegian guidelines. ${ }^{24}$

The recommended discount rate itself is the sum of a risk-free rate and a risk premium. For the risk-free component, the scientific background to the Danish discounting guidelines acknowledges that there is no single correct approach (Finansministeriet, 2018). For example, the Ramsey Rule, which is the workhorse representation of the social discount rate in a 'normative' framework, where ethical matters of intertemporal equity are explicitly addressed, is both unobserved in the data and contentious. By contrast, more 'positive' financial markets-based arguments for determining a cost of capital frequently confuse private sector and social required rates of return. Beyond reviewing the literature, the scientific background considers structural estimates to putting a number to the social discount rate that can be said to incorporate both positive and normative elements, but is more greatly swayed by the former. Based on these considerations, including the inspection of the return on government bonds, the real risk-free discount rate is set at 2.5 percent for the first 35 years of any project's life.

The recommended discount rate also includes a risk premium for 'systematic risk'. This reflects the components of a project's revenues that positively covary with the revenues from other public projects and so cannot be diversified away. Following Norwegian guidance, the premise in Denmark is that the same risk premium should be applied to all projects. This is justified through the recommendation that the discount rate should not be based on each individual project's systematic risk. Instead, the average systematic risk across all public projects is captured in a single risk premium of $1.5 \%$ for horizons of less than 35 years, and this has to be applied to all projects. This is said to give a consistent basis for cost-benefit analyses between sectors. ${ }^{25}$ The scientific background states that if risk is unsystematic in the sense that it is linked to a specific project and can be diversified away because it does not covary with the benefits from other public projects, it should be dealt with in sensitivity analysis and not by adjusting the return requirement.

Danish guidance also acknowledges that the appropriate discount rate should vary with the maturity of the project: a characteristic known as the 'term structure of discount rates'. ${ }^{26}$ As discussed in the scientific background, both the risk free component and the risk premium fall over time, justified by theoretical arguments that uncertainty about the future implies a declining discount rate. The precise discount rate is inspired by the Norwegian guidelines (NOU, 2012). According to the scientific background; for very long-term projects, the part of the project's net benefits realized during the first 35 years are discounted at 4 percent per year, while net benefits that lie between year 36 and year 70 are discounted at a rate of 3 percent, and then 2 percent beyond 70 years.

The sector specific guidelines for practitioners in the energy field follow the general guidelines closely when it comes to the return requirement (Energistyrelsen, 2018). It specifically emphasises the need for analysis of the business case and user side in addition to benefit-cost analyses, with the aim of identifying and defining the relevant projects. There is clearer language, but somewhat different guidance, on unsystematic risk, saying that this should be dealt with by adjusting the social discount rate in the sensitivity analysis.

TABLE 1. THE TERM STRUCTURE OF THE DISCOUNT RATE

\begin{tabular}{lrrr} 
& $\mathbf{0 - 3 5}$ years & $\mathbf{3 6 - 7 0}$ years & $\mathbf{7 0}$ years \\
Real discount rate & $34 \%$ & $3 \%$ & $2 \%$ \\
& & Comprised of & \\
Risk-free component & $2.5 \%$ & $2.25 \%$ & $2 \%$ \\
+ Risk premium & $1.5 \%$ & $0.75 \%$ & $0 \%$ \\
\hline
\end{tabular}

Note. From Finansministeriet, 2018. Presents the guideline's recommendation for the term structure of the discount rate, which, aside from a limited number of exceptions, is applied widely across the public sector in Denmark. The required real rate of return is set to 4 percent for costs and benefits that fall with the span of the NPV analysis of the Aalborg geothermal plant.

\footnotetext{
${ }^{24}$ Respectively Finansministeret, 2017. Vejledning i samfundsøkonomiske konsekvensvurderinger and Finansdepartementet, 2014. Prinsipper og krav ved utarbeidelse av samfunnsøkonomiske analyser mv. Rundskriv R-109/ 14.

25 See Nesje and Lund (2018) for a discussion of this claim.

26 E.g., Gollier and Weitzman (2010); Weitzman (2001); Weitzman (2010). A summary of the academic case is given in Cropper et al. (2014).
} 
TABLE 2. INTERNATIONAL DISCOUNTING GUIDELINES

\begin{tabular}{|c|c|c|c|c|c|}
\hline Country & $\begin{array}{l}\text { Risk-free } \\
\text { discount rate } \\
(\text { in } \%)\end{array}$ & Rationale & $\begin{array}{l}\text { Risk premium } \\
\text { (in \%) }\end{array}$ & $\begin{array}{l}\text { Overall } \\
\text { discount rate } \\
\text { (in \%) } \\
\text { (short to } \\
\text { medium term) }\end{array}$ & $\begin{array}{l}\text { Long-term discount rate } \\
\text { (in } \%)\end{array}$ \\
\hline United Kingdom & $3.5 \%$ & $\begin{array}{l}\text { Simple Ramsey } \\
\text { Rule, SRTP. } \\
\text { Growth risk not } \\
\text { incorporated, } \\
\text { project risk } \\
\text { is minor }\end{array}$ & $\begin{array}{l}0 \% \text {, although } \\
3.5 \% \text { contains } \\
1 \% \text { for } \\
\text { "catastrophic risk }\end{array}$ & $\begin{array}{l}\text { For all } \\
\text { projects and } \\
\text { regulatory } \\
\text { analysis: } \\
3.5 \%\end{array}$ & $\begin{array}{l}\text { The forward rate (in \%) } \\
\text { for time horizon in years }(\mathrm{H}) \\
\text { is respectively: } \\
\mathrm{H}=(0-30,31-75 \\
76-125,126-200 \\
201-300,301+) \\
\mathrm{SDR}=(3.5 \%, 3 \% \\
2.5 \%, 2 \%, 1.5 \%, 1 \%)\end{array}$ \\
\hline United States & $\begin{array}{l}\text { For CBA: } \\
3 \% \text {, with } \\
\text { sensitivity } \\
\text { up to } 7 \%\end{array}$ & $\begin{array}{l}3 \%= \\
\text { consumption } \\
\text { rate of interest, } \\
\text { risk-free } \\
\text { (SOC/SRTP). } \\
7 \%=\text { average } \\
\text { corporate returns } \\
\text { (SOC) }\end{array}$ & $\begin{array}{l}7 \% \text { is a risky } \\
\text { rate of return, } \\
\text { but no project } \\
\text { specific risk } \\
\text { premia }\end{array}$ & $\begin{array}{l}\text { Depending } \\
\text { on source of } \\
\text { funding, projects } \\
\text { and regulatory } \\
\text { analysis: } \\
3 \text { to } 7 \%\end{array}$ & $\begin{array}{l}\text { OMB }(2003) \\
\text { recommends lower rate for } \\
\text { "intergenerational" projects, } \\
\text { for USEPA }(2010) \\
\text { recommends } 2.5 \%\end{array}$ \\
\hline United States & $\begin{array}{l}\text { For CEA: } \\
2 \%\end{array}$ & SRTP & None & $2 \%$ & $\begin{array}{l}\text { No guidance on } \\
\text { long-term CEA }\end{array}$ \\
\hline France & $2.5 \%$ & $\begin{array}{l}\text { Quinet (2013), } \\
\text { Risk free } \\
\text { rate of return. } \\
\text { (Note, } \\
\text { Lebegue, 2005 } \\
\text { Ramsey Rule) }\end{array}$ & $\begin{array}{l}\text { Beta * } 2 \%, \\
2 \% \text { comes from } \\
\text { the estimated risk } \\
\text { of "deep recession", } \\
\text { see Barro (2006) }\end{array}$ & $\begin{array}{l}\text { For risky } \\
\text { projects: } \\
2.5 \%+\text { Beta } * \\
2 \%\end{array}$ & $\begin{array}{l}\text { Risk free rate: declining to } \\
1.5 \% \text { after } 2070 \text { time } \\
\text { horizon.Risky premium: } \\
2 \% \text { for Beta }=1 \text { rising } \\
\text { to } 3.5 \% \text { after } 2070 \text { time } \\
\text { horizon }\end{array}$ \\
\hline Norway & $2.5 \%$ & $\begin{array}{l}\text { Risk-free } \\
\text { return to } \\
\text { government } \\
\text { bonds }\end{array}$ & $\begin{array}{l}1.5 \% \text { systematic } \\
\text { risk premium, } \\
\text { fixed for all projects }\end{array}$ & $\begin{array}{l}\text { For all projects } \\
\text { and regulatory } \\
\text { analysis: } 4 \%\end{array}$ & $\begin{array}{l}\text { Risk free rate declining to } \\
2 \% \text { after } 75 \text { years. } \\
\text { Risk premium to } \\
0 \text { after } 75 \text { years. }\end{array}$ \\
\hline Netherlands & $-1 \%$ & $\begin{array}{l}\text { CAPM, } \\
\text { opportunity cost } \\
\text { Approach }\end{array}$ & $\begin{array}{l}3.25 \% \text { systematic } \\
\text { risk premium, } \\
\text { fixed for all projects }\end{array}$ & $\begin{array}{l}2.25 \% \text {, except } \\
\text { for fixed sunk } \\
\text { costs and highly } \\
\text { non-linear } \\
\text { benefits }\end{array}$ & $\begin{array}{l}\text { Accepts DDRs, but opted } \\
\text { for fixed risk free rate of }-1 \% \text {, } \\
\text { and fixed systematic risk } \\
\text { premium }\end{array}$ \\
\hline
\end{tabular}

Note. From OECD (2018), updated based on new guidance in the Netherlands (Centraal planbureau, 2020). The table clarifies

Note. From OECD (2018). Updated based on new guidance in the Netherlands (Centraal planbureau, 2020). The table clarifies motivations for the choice of the social discount rate (SDR). Here, the CAPM beta is a device to construct the risk premia. The Ramsey Rule's Societal Rate of Time Preference (SRTP) is generally considered to be normative. The Capital Asset Pricing Model (CAPM) and Social Opportunity Cost (SOC) are generally positive. Discount rates that are declining with the horizon, so-called declining discount rates (DDRs), are also prevalent in guidelines. Guidelines relate either to cost-effectiveness analysis (CEA), cost-benefit analysis (CBA), or both. 


\subsection{DIFFERENT INTERNATIONAL CHOICES OF DISCOUNT RATE}

While the real social discount rate in Denmark is 4 percent for costs and benefits arising within the first 35 years, it is clear from Table 2 that it varies across OECD countries. ${ }^{27}$ Starting with the risk-free component of the discount rate, and going from the lowest to the highest for the short- to medium-term:

- In the Netherlands, the real risk-free discount rate is -1 percent and based primarily on positive consideration of real yields that are currently available on Government bonds. This is the most recent recommendation on discount rates from a major OECD country and could be informative in the Danish context for how to account for lower return requirements in the current economic context.

- The United States' real risk-free discount rate is 2 percent for cost-effectiveness (CEA), but not cost-benefit analysis (CBA). This is motivated by explicit 'normative' considerations of intergenerational welfare. The relevance of this rate in the Danish context is not clear as the Aalborg case is evaluated under CBA rather than CEA.

- France's short- to medium-term real risk-free discount rate is 2.5 percent, and is identical to the risk-free discount rate in Denmark. It is declining over time, motivated by normative considerations, and may be informative in the Danish context for thinking about how to account for explicitly ethical motivations for declining discount rates. This contrasts with the more positive Danish approach, although some of these normative rationales are discussed in the scientific background to the Danish guidelines.

- As explained above, Norway's guidance is highly similar to that in Denmark, but with a slightly different term structure of declining rates.

- The United States' recommendation is that real discount rates of both 3 percent and 7 percent should be applied as sensitivity analysis in CBA. The 7 percent, though, cannot be considered to be risk-free because it relates to the required rate of return on private capital, which includes a risk premium for real investment. In some environmental contexts, which may be of more relevance to the Green Transition, rates of 2.5, 3 and 5 percent are used instead (Greenstone et al., 2013). These reflect a blend of positive and normative considerations, with the 3 percent rate being primarily a positive real risk-free rate.

- The United Kingdoms' short- to medium-term real risk-free discount rate is 3.5 percent, driven by normative considerations. However, this includes $1 \%$ for 'catastrophic risk', which may be considered to be a type of risk premium. This guidance has influenced current Danish thinking on the risk-free discount rate.

Overall, the Danish real risk-free rate of $2.5 \%$ falls very much in the middle of the guidance provided by OECD countries, although the Dutch currently use a substantially lower rate. It is also close to the average rate recommended by academic experts in the field (Drupp et al., 2018).
We can also see from Table 2 that different countries take very different approaches to risk premiums in the discount rate. The Netherlands also has a fixed risk premium of $3.25 \%$, higher than the guidelines in Denmark and partially offsetting the lower risk-free rate. The 1 percent 'catastrophic risk' component of the UK's overall 3.5 percent social discount rate aims to capture a range of factors that vary from the possibility of societal collapse to the systematic risk of average public projects. As mentioned above, the upper 7 percent rate in the US captures the risk inherent in private investment, while the 5 percent rate used in some environmental contexts attempts to capture the average systematic risk of environmental projects.

The French guidance is particularly interesting as it varies the risk premium between different projects based on their individual systematic risk, rather than the average risk across public projects. This is clearly theoretically correct, but can be difficult to estimate in practice. Based on the work of Christian Gollier, which contrasts with the theoretical work that underpins the Danish guidance, the risk premium increases rather than decreases over time (e.g., Gollier, 2014). This offsets the declining risk-free component of the discount rate and, depending on the individual systematic risk of the project, can result in declining, flat, or rising term structures for the social discount rate. This is not relevant for the Aalborg project, however, because of its relatively short maturity.

An area where we believe that the Danish sectoral guidelines needs some revision is the recommendation that sensitivity should be undertaken on the discount rate to account for unsystematic risk. Under standard theoretical models, unsystematic risk does not influence the discount rate, but instead should be included in the estimation of the expected cash flow, and, potentially, cash flow sensitivity analysis. This is consistent with the general Danish scientific guidance on the treatment of unsystematic risk.

\subsection{THE SENSITIVITY OF THE SOCIO-ECONOMIC ANALYSIS TO THE CHOICE OF DISCOUNT RATEE}

Given these different approaches to social discounting in different international contexts, the question arises as to whether the relative socio-economic attractiveness of the geothermal plant and the woodchip CHP plant could be reversed under other 'reasonable' discounting assumptions. To answer this question, we deduct the woodchip CHP plant costs from the geothermal plant costs in each year to construct a series of 'net costs'. In the early years, this series is positive because of the low costs of running out the existing coal plant. However, in later years, the geothermal costs are lower, meaning that the 'net costs' series becomes negative. Importantly, the sign of the series changes only once: from positive to negative in 2027 .

Because this 'net costs' series changes sign only once, the internal rate of return (IRR) that sets the present value of this series to zero - implying that the two alternatives are equally socio-economically attractive - is unique. If the discount rate is below this unique IRR, then the geothermal project will be preferred because its long-term benefits are discounted at a lower rate. For higher discount rates, the woodchip CHP plant would be preferred because its benefits arise in earlier years. 


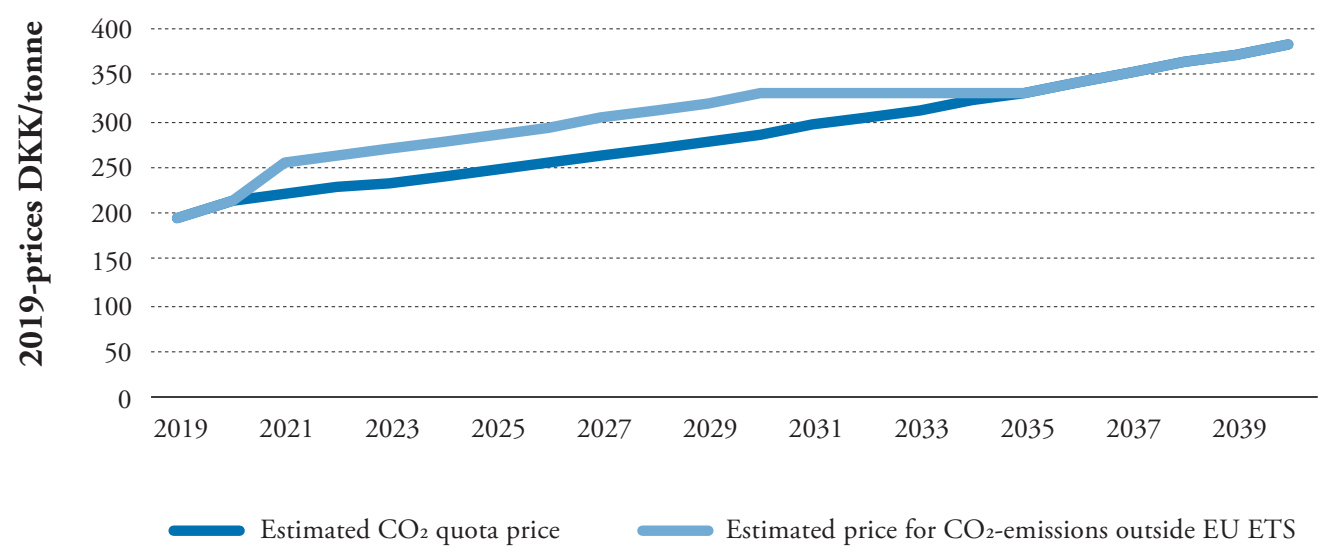

FIGURE 4. PROJECTED CO 2 PRICES EXCLUDING TAXES. SOURCE: DATA BASED ON DANISH ENERGY AGENCY (2019). ${ }^{31}$

We calculate this unique IRR to be equal to $15.25 \%$. This is considerably above the discount rate used by any OECD country. Given this, we can conclude that the socio-economic preference for the geothermal plant is not driven by the specific discounting choices made by the Aalborg municipal council. However, this may not generally be the case for Green Transition projects in Denmark.

\section{COSTS OF CAPITAL IN THE CASH FLOW ESTIMATES}

At first sight, the discount rate used in the socio-economic analysis of the Aalborg geothermal plant follows both the sectoral and overall governmental guidance that is applied in Denmark. In this section, though, we argue that a number of the costs that are included in the analysis incorporate real costs of capital that differ from the 4 percent discount rate that underlies the project's core NPV calculation. The calculation assumptions are given by the Danish Energy Agency. ${ }^{28}$

\section{1. $\mathrm{CO}_{2}$ PRICES}

$\mathrm{CO}_{2}$ prices are used in relation to emissions from fuel and electricity consumption and electricity production. The costs of emissions are calculated for sectors inside and outside the EU ETS, and these are subject to multiplication by the conversion factor in socio-economic analyses. ${ }^{29}$
The price of electricity includes the associated $\mathrm{CO}_{2}$ emission costs, because it is the electricity producer who pays for the emission permits under the EU ETS scheme. $\mathrm{CO}_{2}$ emission costs from electricity consumption are thus not to be included as additional costs in relation to electricity. ${ }^{30}$ However, other greenhouse gas emissions are not included in electricity prices and have to be accounted for separately. These emissions, excluding $\mathrm{CO}_{2}$, are priced as $\mathrm{CO}_{2}$-equivalent emissions outside the EU ETS. Price projections are shown in Figure 4.

For emissions inside the EU ETS, the price is based on the current market price of $\mathrm{CO}_{2}$, projected forward using a discount rate based on the real return on a risk-free asset (the rate on German 10-year government bonds) plus a risk premium of 3.5 percent annually. ${ }^{32}$ As of June 2020, this was a discount rate of approximately 3.3 percent. ${ }^{33}$ This methodology, developed by the Danish Ministry of Finance, assumes that the cost of emission allowances follows companies' expected financing costs. ${ }^{34}$ The future price projections are thus entirely detached from any changes to national or EU targets, instead being based purely on considerations of financing costs, not policies or actions that relate to the EU ETS or the energy system broadly.

For emissions outside the EU ETS, costs are set to the expected reduction costs for reaching a set emission target. ${ }^{35}$ The cost is anchored in a 2030-projection of 40 EUR-2010 ${ }^{36}$ per tonne of $\mathrm{CO}_{2},{ }^{37}$ which is then interpolated back to preceding years using the EU ETS price trend. ${ }^{38}$ The 2030 value is based on the modelling of the European Commission's scenario GHG40, which assumes 40\% greenhouse gas reductions by 2030 when compared to $1990 .{ }^{39}$ The PRIMES model is used as the basis for

\footnotetext{
28 Energistyrelsen, 2019. Samfundsøkonomisk beregningsforudsætninger for energipriser og emissioner.

29 Energistyrelsen, 2019. Samfundsøkonomisk beregningsforudsætninger for energipriser og emissioner, p. 28.

30 Energistyrelsen, 2018. Vejledning i samfundsøkonomiske analyser på energiområdet, p. 18.

31 From data in Energistyrelsen, 2019. Samfundsøkonomisk beregningsforudsætninger for energipriser og emissioner, p.15.

32 Energistyrelsen, 2019. Samfundsøkonomisk beregningsforudsætninger for energipriser og emissioner, p. 28.

33 Derived from the numbers presented in Energistyrelsen, 2020c. Basisfremskrivninger for $\mathrm{CO}_{2}-\mathrm{kvotepriser}$.

${ }^{34}$ Energistyrelsen, 2020c. Basisfremskrivninger for $\mathrm{CO}_{2}$-kvotepriser, p.2.

35 Energistyrelsen, 2019. Samfundsøkonomisk beregningsforudsætninger for energipriser og emissioner, p. 27.

36 E2010-price level described for the Reference Scenario in European Commission, 2014. A Policy Framework for Climate and Energy from 2020 to 2030 , p. 29.

37 European Commission, 2014. A Policy Framework for Climate and Energy from 2020 to 2030, p. 59.

38 Energistyrelsen, 2019. Samfundsøkonomisk beregningsforudsætninger for energipriser og emissioner, p.28.

39 European Commission, 2014. A Policy Framework for Climate and Energy from 2020 to 2030, p. 41.
} 
TABLE 3. WACC RATES APPLIED IN THE PRIMES MODEL

\begin{tabular}{lrrr} 
WACC rates (real) & $\begin{array}{c}\text { Standard discount } \\
\text { rate of PRIMES }\end{array}$ & \multicolumn{2}{c}{$\begin{array}{c}\text { Modified discount rates } \\
\text { due to EED* }\end{array}$} \\
\cline { 3 - 4 } & & $\mathbf{2 0 1 5}$ & $\mathbf{2 0 2 0 - 2 0 5 0}$ \\
Power generation & $12 \%$ & $9 \%$ & $9 \%$ \\
Industry & $12 \%$ & $12 \%$ & $12 \%$ \\
Tertiary & $8 \%$ & $11 \%$ & $10 \%$ \\
Public transport & $12 \%$ & $12 \%$ & $8 \%$ \\
Trucks and inland navigation & $17.50 \%$ & $17.50 \%$ & $17.50 \%$ \\
Private cars & $17.50 \%$ & $14.75 \%$ & $12 \%$ \\
Households & & \\
\hline
\end{tabular}

Note. EED refers to the Energy Efficiency Directive. The EED's expected facilitation of institutions, certifications and controls translate into an expectation of reduced risk and the associated discount rates. Adapted directly from the original table. ${ }^{40}$

calculating this scenario, and this incorporates assumptions about several different sectoral weighted average costs of capital (WACC), which again differ from the social discount rate of 4 percent used in the Aalborg project's NPV calculation. These are summarised in Table 3.

The modelling documentation describes the approach as follows: "The PRIMES model is based on individual decision making of agents demanding or supplying energy and on price-driven interactions in markets. The modelling approach is not taking the perspective of a social planner and does not follow an overall least cost optimization of the entire energy system in the long-term. Therefore, social discount rates play no role in determining model solutions". ${ }^{41}$ The cost of non-EU
ETS emissions of 40 EUR-2010 per tonne of $\mathrm{CO}_{2}$ is thus a 2030-cost, derived from modelling different agents with varying private real discount rates. ${ }^{42}$ This absence of social discounting has been criticised by Ecofys, which suggests a level of 3-6 percent. ${ }^{43}$

\subsection{ELECTRICITY AND FUEL PRICES}

Electricity price projections are based on the RAMSES model towards 2030 , assuming an amount of renewable electricity equal to the Danish demand. ${ }^{44}$ The projected price to 2040 is shown in Figure 5.

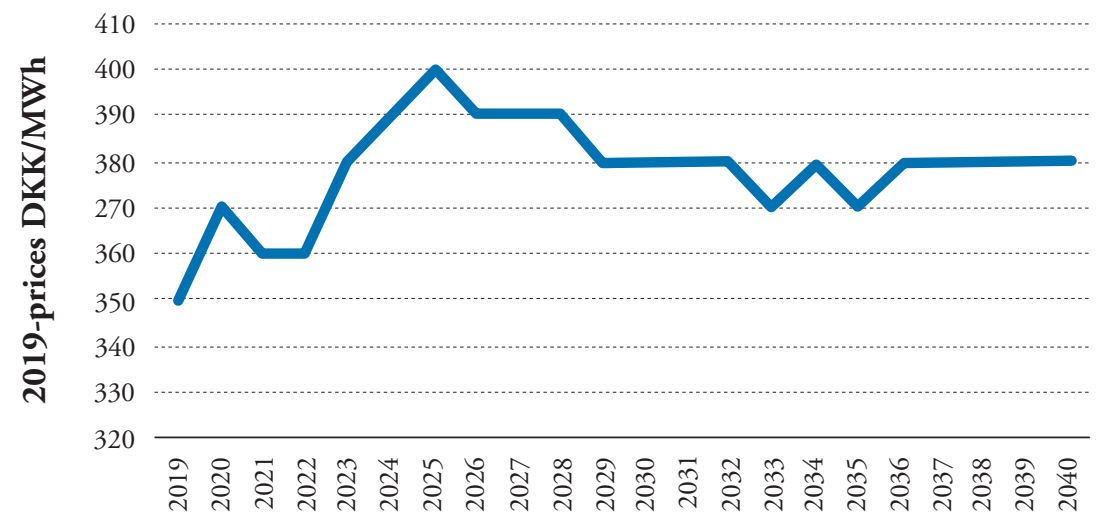

Raw socio-economic price of electricity

\section{FIGURE 5. RAW SOCIO-ECONOMIC ELECTRICITY PRICES WITHOUT TAXES. SOURCE: DANISH ENERGY AGENCY (2019). 45}

\footnotetext{
40 Energistyrelsen, 2019. Samfundsøkonomisk beregningsforudsætninger for energipriser og emissioner.

41 European Commission, 2013. Energy Trends towards 2050, p. 25.

42 European Commission, 2013. Energy Trends towards 2050. p. 25.

43 European Commission, 2015. Evaluating our future: The Role of Discount Rates, p.32.

44 Energistyrelsen, 2019. Samfundsøkonomisk beregningsforudsætninger for energipriser og emissioner, p. 15.

45 Data from Energistyrelsen, 2019. Samfundsøkonomisk beregningsforudsætninger for energipriser og emissioner, p. 15.
} 


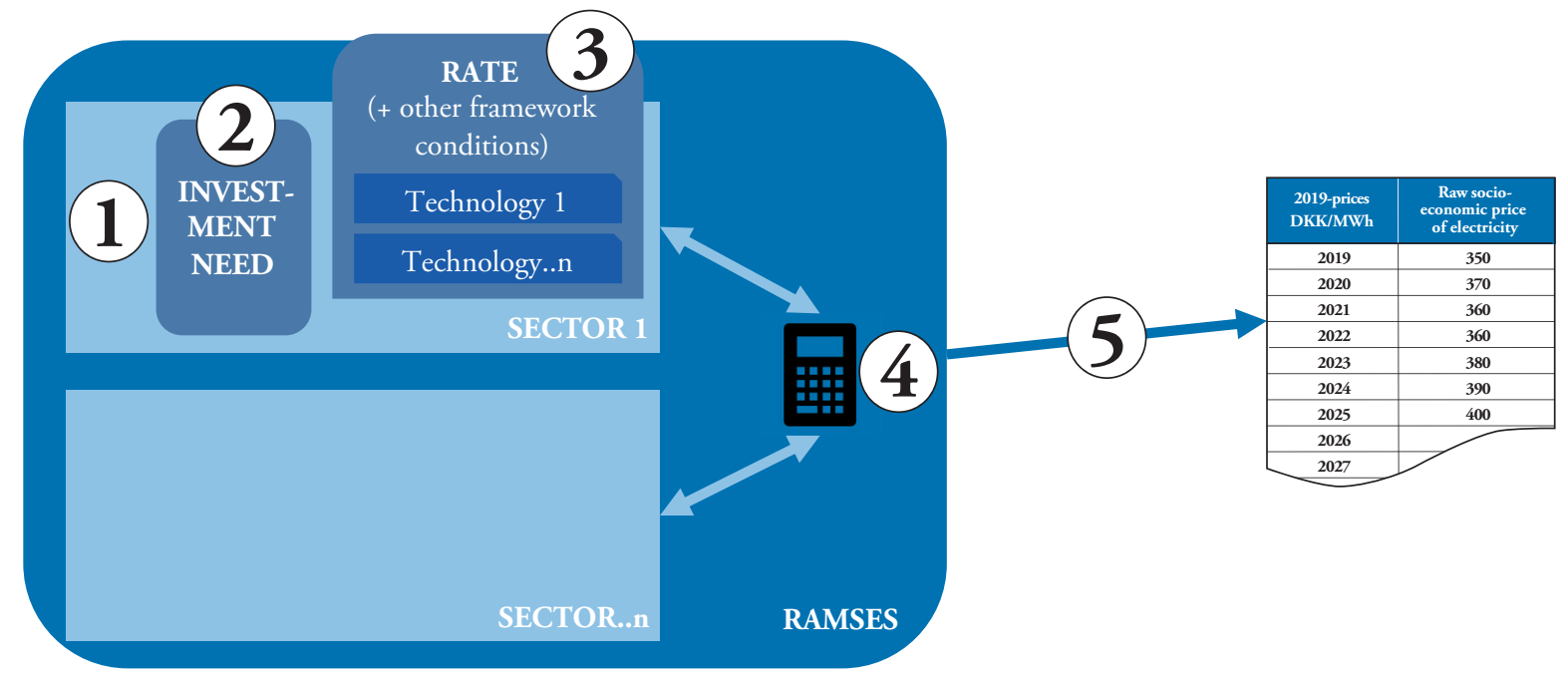

FIGURE 6. AN ILLUSTRATION OF THE RAMSES MODEL. SOURCE: OWN ILLUSTRATION.

The RAMSES model is an hourly power market equilibrium model that includes Northern Europe. ${ }^{46}$ The modelling in RAMSES is illustrated in Figure 6. Several sectors and actors are represented in the model. Specifically, (1) the modelling is conducted as an operational optimisation; (2) projected capacities are fed into RAMSES from external modelling and manual estimates. Subject to various framework conditions (3), the RAMSES modelling finds a market equilibrium (4) and outputs electricity prices, based on simulations of generators' and consumers' operation and investment (5). The model thus does not optimise according to a common social discount rate. Rather, it identifies the equilibrium of various sectors' operational and investment decisions. ${ }^{47}$

The RAMSES model builds on various inputs. For fossil fuels, a weighted price between forward prices and the Stated Policies Scenario in the IEA's World Energy Outlook (WEO) is applied. ${ }^{48}$ Woodchip prices are applied in the RAMSES model ${ }^{49}$ as well as directly in the CHP alternative to the Aalborg geothermal project. As the market for woodchips is considered too small and illiquid to generate useful forward prices, ${ }^{50}$ the projected price is based on "raw biomass price from forest in the exporting country, profit margin for the biomass producer, costs for treatment, transport costs and costs for freight to a Danish harbour". ${ }^{51}$ The raw woodchip prices are adapted to Danish numbers from the Global Change Assessment Model (GCAM), 52 which is a market equi- librium model, 53 similar to RAMSES and the World Energy Model (WEM). Thus, GCAM does not optimize according to a global, social discount rate, ${ }^{54}$ but represents different sectors and agents. Documentation is limited, but it appears that a fixed charge rate is set at $13 \%$ for technology costs. This rate includes "depreciation, interest rate, taxes and return on equity". ${ }^{55}$

The IEA's World Energy Outlook is based on WEM. The documentation indicates a similar approach to the one applied in RAMSES: a market equilibrium model with no global, social discount rate, but an aggregate output of private economic actions among simulated sectors. The WACC (pre-tax, real terms) is overall assumed to be 7 percent $/ 8$ percent for non-OECD/OECD countries. ${ }^{56}$ However, there is some deviation from this as noted in the model documentation: "Within WEO-2020, more detailed financing cost analysis was performed for utility-scale solar PV projects, shale companies, coal mining companies, and for economy-wide comparisons of advanced with emerging market and developing economies. These assessments were derived from country level data on risk-free rates, market risk premiums and project/company-specific risk premiums obtained from Bloomberg, Thomson Reuters and Damodaran Online, as well as sector-specific sources and analysis". ${ }^{57}$

\footnotetext{
46 Market equilibrium model' here denotes a type of modelling that simulates market actions. This is in contrast to system/market 'optimisation' models like the Balmorel model. See Wiese, R. Bramstoft, H. Koduvere, A. Pizarro-Alonso Alonso, O. Balyk, J.G. Kirkerud, Å.G. Tveten, T.F. Bolkesjø, M. Münster, H. Ravn, Balmorel open source energy system model.

47 Personal dialogue with Mette Larsen, Danish Energy Agency, December 2020

48 Energistyrelsen, 2020b. Baggrundsnotat: Brændselspriser til fremskrivninger, p. 3.

49 Energistyrelsen, 2019. Samfundsøkonomisk beregningsforudsætninger for energipriser og emissioner, p. 15.

50 Energistyrelsen, 2020b. Baggrundsnotat: Brændselspriser til fremskrivninger, p. 3.

51 Own translation from Danish: Energistyrelsen, 2020a. Baggrundsnotat: Brændselspriser til fremskrivninger, p. 9.

52 https://ens.dk/sites/ens.dk/files/Analyser/analysis_of_biomass_prices_2013.06.18__ffinal_report.pdf, p. 5.

53 Pacific Northwest National Laboratory, 2018. Overview of the Global Change Assessment Model (GCAM), p. 12.

54 Pacific Northwest National Laboratory, 2018. Overview of the Global Change Assessment Model (GCAM) and Joint Global Change Research Institute, 2020. GCAM Documentation p. 12.

55 Fraunhofer, 2018. Comparison of technology cost assumptions from MESSAGE and GCAM, p. 8 and

Pacific Northwest National Laboratory, 2020. Improving the Representation of Investment Decisions in Integrated Assessment Models, p.3.

56 International Energy Agency, 2020. World Energy Model p. 37.

57 International Energy Agency, 2020. World Energy Model, p. 72
} 
TABLE 4. WACC RATES APPLIED IN THE PRIMES MODEL

\begin{tabular}{llllc} 
2019-prices & Sector & $\mathbf{S O}_{2} / \mathbf{S O}_{4}$ & NOx & PM2.5 \\
DKK/kg & & 20 & 15 & 47 \\
SNAP 1 & Larger combustion units, incl. waste incinerators & 58 & 50 & 173 \\
SNAP 2 & Combustion units in households etc. & 28 & 20 & 56 \\
SNAP 3 & Industrial combustion units & 28 & \\
\hline
\end{tabular}

Note. From Danish Energy Agency (2019). ${ }^{58}$ SNAP: Selected Nomenclature for Air Pollution - an internationally standardised division of sectors. Damage costs are presented as consumer costs and are thus not subject to multiplication by the net tax factor. Table is translated from original Danish version. The numbers derive from the now obsolete Miljøøkonomiske beregningspriser for emissioner 2.059 from 2018, superseded by a 2019 update. $^{60}$

\subsection{ENVIRONMENTAL DAMAGES}

$\mathrm{SO}_{2}, \mathrm{NO}_{\mathrm{x}}$ and PM2.5 Table 4 are valued according to their marginal damage costs within Danish borders.

Damage costs are calculated in the Economic Valuation of Air Pollution Model System (EVA). For the first 35 years, discounting is at 4 percent, then 3 percent for years 35-70 and then 2 percent for later years. This is consistent with the general Danish socio-economic guidelines shown in Table 1.

Figure 7 summarises the cost of capital assumptions that are applied in the pricing forecasts that are included in the socio-economic analysis of the Aalborg geothermal district heating $(\mathrm{DH})$ project and the woodchip CHP alternative. The variations in the financing assumptions across the different models are clear.

\subsection{COSTS OF CAPITAL AND THE FINANCIAL ANALYSIS OF THE AALBORG GEOTHERMAL PLANT}

There is one further place where costs of capital arise in the analysis of the Aalborg geothermal plant. This is not in the socio-economic analysis, and hence does not affect the relative social attractiveness of the geothermal plant against the woodchip CHP plant. Instead, it lies in the financial analysis that helps determine the price that Aalborg Forsyning can charge to its customers for providing heating.

District heating companies are subject to regulation under the Danish Heat Supply Act, in which pricing is subject to a principle of coverage of necessary costs i.e. limited or no economic profits. ${ }^{61}$ Generally, projects are debt financed and the initial investment costs are recouped through annuity payments passed on to the heat consumers. Further, heat companies are allowed to charge their customers for expected future investments prior to operation, which reduces the need for equity financing. In summary this implies that the borrowing rate is the dominant opportunity cost of capital.

The post-financial crisis debt markets have offered very cheap borrowing rates. In addition, the majority of district heating companies have access to favourable financing conditions through debt contracts guaranteed by a union of municipalities. As of 2020, the municipal creditor Kommunekredit, which provides loans to the district heating sector, sets the nominal rate of 20 -year fixed rate nonconvertible loans at 0.43 percent. ${ }^{62}$

In principle, the cost of financing should not be included in socio-economic cost-benefit analyses as interest payments are not real resource costs. ${ }^{63}$ However, a difference between the financial discount rate and the social discount rate may lead to differences between the financial and the socio-economic rankings of projects. In the geothermal project proposal, the financial NPV analysis employs a 3 percent effective nominal borrowing rate, consisting of 2 percent interest to the lender and 1 percent in guarantee provision to the municipality. ${ }^{64}$ If the borrowing rate is identified as the relevant choice of discount rate, and the inflation projections offered by the Danish Energy Agency are correct, ${ }^{65}$ the real financial discount rate is just above 1 percent for the geothermal project. Using a low discount rate puts relatively less weight on the costs of investment in the NPV compared to the cost of operation. Under current regulation, where municipalities must select the project with the highest socio-economic value, the difference in discount rates can force investments that are not optimal from the private economic

\footnotetext{
58 Energistyrelsen, 2019. Samfundsøkonomisk beregningsforudsætninger for energipriser og emissioner, p. 30.

59 National Center for Miljø og Energi, 2018. Miljøøkonomiske beregningspriser for emissioner.

60 National Center for Miljø og Energi, 2019. Miljøøkonomiske beregningspriser for emissioner, p. 9.

61 With the exception of equity capital from before 1. March 1981, the date where the break-even regulation came into effect. The rate of return has to be 'reasonable' and is subject to approval by the Danish Utility Regulator.

62 Rate as of 1 April 2020 from Kommune Kredit, 2020. Takstberegninger.

63 Squire, L \& van der Tak, H.G. (1975) Economic Analysis of Projects. The Johns Hopkins University Press, published for The World Bank, p. 20.

64 Cowi, 2019. Etablering af 100MW geotermisk anlæg - Projektforslag.

65 Energistyrelsen, 2019. Samfundsøkonomisk beregningsforudsætninger for energipriser og emissioner.
} 


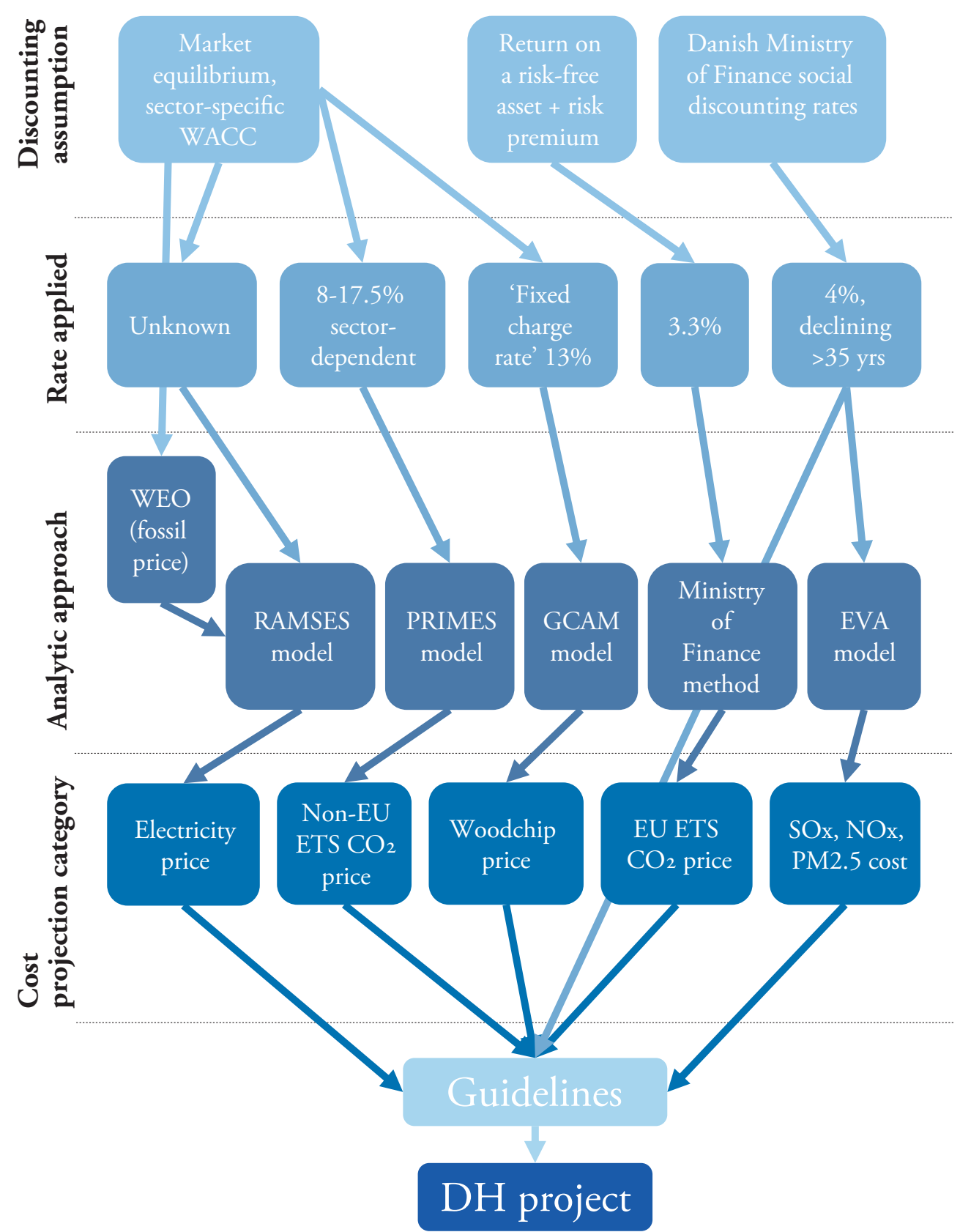

FIGURE 7. DISCOUNTING AND COSTS OF CAPITAL FOR PRICING FORECASTS IN THE SOCIO-ECONOMIC ANALYSIS. SOURCE: OWN ILLUSTRATION.

perspective. This may create a problem, since the socio-economic cost-benefit analyses should rank projects identified and defined as relevant in part based on the analysis of the business case. ${ }^{66}$

In its guidelines, the Danish Ministry of Finance argues that the socio-economic discount rate has to be higher than the current borrowing cost of funds, as it needs to account for macroeconomic externali- ties, such as long term output losses due to economic instability caused by overinvestment. ${ }^{67}$ It should be noted, however, that energy sector investments that benefit the environment are often capital intensive with lower operational costs, and the higher discount rate tends to favour incumbent fuel-based technologies. ${ }^{68}$

\footnotetext{
66 Energistyrelsen, 2018. Vejledning i samfundsøkonomiske analyser på energiområdet.

67 Finansministeriet, 2018. Den samfundsøkonomiske diskonteringsrente, p. 4.

68 e.g. Hirth, L., \& Steckel, J.C. (2016) The role of capital costs in decarbonizing the electricity sector. Environmental Research Letters $11,114010$.
} 


\section{DISCUSSION AND CONCLUSION}

When choosing between different energy projects, appraisers are legally required to select the one with the highest socio-economic value. This socio-economic analysis requires the use of a discount rate to weigh the costs that arise today against future benefits, and in the Danish energy regulation context, the prescribed "headline" discount rate is set at 4 percent real. However, because greenhouse gasses remain in the atmosphere for many generations, Green Transition projects have benefits that accrue over centuries. Furthermore, the Green Transition projects tend to be very capital intensive. The socio-economic analysis of such projects is therefore highly sensitive to this choice of discount rate. If the rate is "too high", this is likely to lead to the "false" rejection of projects that will aid in the Green Transition. Energy regulation in Denmark therefore has an obligation to be certain about the discount rate that it applies in this context. It has also traditionally been outside the realm of the regulator to ensure alignment between the socio-economic and private economic desirable outcome. A starting point for the regulator, under the Green Transition, could be to explore whether there is indeed discrepancy between these outcomes in submitted project proposals.

Our analysis has revealed that the socio-economic and financial analyses of the Aalborg geothermal plant and its alternative contain a number of different assumptions concerning discount rates, annuity rates and costs of capital, some of which differ markedly from the "headline" 4 percent real rate. For each input, the different underlying models incorporate relevant social, financial and commercial factors and reflect these into the rates that they use. But some of the differences in rates used are stark. Section 5.1 shows that the PRIMES model uses corporate weighted average costs of capital that are 8 percent real and higher, while, in section 5.2, GCAM appears to be using rates of 13 percent. By contrast, section 5.3 shows that the EVA model values environmental damages using the standard 4 percent social discount rate that is also used in the socio-economic NPV calculation, while the financial analysis in section 5.4 uses an annuity rate of close to 1 percent real.

While all the different choices are carefully considered, what we cannot be confident about at this stage is their consistency. As described in Section 4, different OECD countries reach very different conclusions about how social discounting should be undertaken. Choices reflect different views on: (i) the relative weight placed on normative and positive considerations of social discounting, (ii) how discount rates should vary depending on the maturity of the project, and (iii) the treatment of systematic and other risks. The analysis undertaken within each country is very careful, but there are inconsistencies between different countries. To our knowledge, Danish energy authorities do not have any overarching economic, financial and ethical framework that ensures that intertemporal welfare matters are consistently applied in each of the different model inputs.

While it is particularly difficult to see why PRIMES and EVA use such different rates when they are both considering environmental damages, we should make it clear that using different rates in different contexts does not necessarily imply that there are inconsistencies between models. There may be very good reasons why each applies a different social rate, bond yield, or WACC. Our central observation is that, currently,
Danish energy authorities may not be in a position to reach a conclusion on this issue one way or the other because each input model has been constructed independently of the others.

These issues potentially make a practical difference. While we do not necessarily advocate this approach, suppose that Danish energy regulation required municipalities to apply social discount rates uniformly across all inputs to the socio-economic analysis. This policy choice would generally make Green Transition projects appear more attractive compared to their alternatives, given the long-term benefits that arise from them, meaning that there would be more rapid progress towards environmental targets. For example, a recent study of the Social Cost of Carbon that aligns the DICE climate-economics model with UN climate targets based on the use of risk-free social discount rates estimates a value of approximately USD100-200 per ton of $\mathrm{CO}_{2} \cdot{ }^{69}$ This range is substantially higher than the values described in Section 5.1 and, if applied by the Aalborg municipal council, would likely lead to an even stronger case for the geothermal plant because of its lower emissions. While this change of modelling assumption would not alter the decision to invest in the geothermal plant in this instance, it might in other circumstances lead to the acceptance of some Green Transition projects that had previously been rejected in favour of the alternative. This, in turn, will help the Danish government achieve its aim of cutting emissions by $70 \%$ before 2030 .

\section{REFERENCES}

Aalborg Forsyning, 2019. Udbud af Geotermi. https://www.ethics.dk/ethics/eo\#/bf713ae0181b-4e62-b0b3-a2631a8a6678/publicNotice (accessed 22 January 2021).

Aalborg Forsyning, 2019. Årsrapport 2019: Varme. https://aalborgforsyning.dk/medial c13k4e2w/aalborg_varme_2019_\%C3\%A5rsrapport.pdf (accessed 21 January 2021).

Aalborg Forsyning, 2020. Udbud af geotermianlæg. https://aalborgforsyning.dk/privat/ nyheder-og-presse/seneste-nyheder/18-december-2020-aalborg-forsyning-indstiller-udbud-af-100-mw-geotermianlaeg/ (accessed 22 January 2021).

Atkinson, G., Groom, B., Hanley, N., \& Mourato, S. (2018). Environmental valuation and benefit-cost analysis in UK policy. Journal of Benefit-Cost Analysis, 9(1), 97-119.

Centraal planbureau, 2020. Rapport Werkgroep discontovoet 2020. https://www.rijksoverheid.nl/documenten/kamerstukken/2020/11/10/rapport-werkgroep-discontovoet-2020 (accessed 22 December 2020)

Cowi, 2019. Etablering af 100MW geotermisk anlæg - Projektforslag. https://www.aalborg. dk/usercontrols/AalborgKommune/Referater/Pdf.aspx?pdfnavn=21237859-22473479-1. pdf\&type=bilag\&pdfid=115663 (accessed 20 January 2021).

Cowi, 2019. Projektforslag: Aalborg Kommune. https://www.aalborg.dk/usercontrols/ AalborgKommune $/$ Referater $/$ Pdf.aspx?pdfnavn=21237859-22473479-1.pdf\&type=bilag\&pdfid=115663 (accessed 21 January 2021).

Cropper, M. L., Freeman, M. C., Groom, B., \& Pizer, W. A. (2014). Declining Discount Rates. American Economic Review, 104(5), 538-43.

Danish Energy Agency, 2020. Geotermianalyse. https://ens.dk/sites/ens.dk/files/Geotermi/ geotermianalyse.pdf (accessed 3 February 2021)

Danish Geothermal District Heating, 2014. Drejebog om geotermi. https://www.geotermi dk/media/3769/drejebogforgeotermi20140121.pdf (accessed 21 January 2021).

Danmarks Statistik, 2020. Folketal 1. januar efter byområder, landdistrikter, alder og køn. https://www.statistikbanken.dk/BY1 (accessed 21 January 2021).

Drupp, M. A., Freeman, M. C., Groom, B., \& Nesje, F. (2018). Discounting disentangled. American Economic Journal: Economic Policy, 10(4), 109-34. 
Ea Energy Analysis, 2013. Analysis of Biomass Prices. https://ens.dk/sites/ens.dk/files/Analyser/analysis_of_biomass_prices_2013.06.18__final_report.pdf (accessed 21 January 2021).

Energistyrelsen, 2018. Vejledning i samfundsøkonomiske analyser på energiområdet. https:// ens.dk/sites/ens.dk/files/Analyser/vejledning_i_samfundsoekonomiske_analyser_paa energiomraadet__ juni_2018_v1.1.pdf (accessed 22 December 2020).

Energistyrelsen, 2019. Samfundsøkonomisk beregningsforudsætninger for energipriser og emissioner. https://ens.dk/sites/ens.dk/files/Analyser/samfundsoekonomiske_beregningsforudsaetninger_for_energipriser_og_emissioner_2019.pdf (accessed 21 January 2021).

Energistyrelsen, 2020a. Baggrundsnotat: Brændselspriser til fremskrivninger. https://ens.dk/ $\underline{\text { sites/ens.dk/files/Basisfremskrivning/baggrundsnotat__ braendselspriser.pdf }(\text { accessed } 21}$ January 2021)

Energistyrelsen, 2020b. Baggrundsnotat: Brændselspriser til fremskrivninger. https://ens.dk/ $\underline{\text { sites/ens.dk/files/Hoeringer/af20__baggrundsnotat_- braendselspriser.pdf (accessed } 21}$ January 2021).

Energistyrelsen, 2020c. Basisfremskrivninger for CO2-kvotepriser. https:/ens.dk/sites/ens.dk/ files/Basisfremskrivning/baggrundsnotat_-_co2-kvotepris_0.pdf (accessed 21 January 2021).

European Commission, 2013. Energy Trends Towards 2050. https://ec.europa.eu/transport/ sites/transport/files/media/publications/doc/trends-to-2050-update-2013.pdf (accessed 21 January 2021).

European Commission, 2014. A Policy Framework for Climate and Energy from 2020 to 2030. https://eur-lex.europa.eu/legal-content/EN/TXT/PDF/?uri=CELEX:52014SC0015\&from=EN (accessed 21 January 2021).

European Commission, 2015. Evaluating our future: The Role of Discount Rates. https:// www.eceee.org/static/media/uploads/site-2/policy-areas/discount-rates/evaluating-our-future-report.pdf (accessed 21 January 2021).

Finansdepartementet, 2014. Prinsipper og krav ved utarbeidelse av samfunnsøkonomiske analyser mv. Rundskriv R-109/ 14. https://www.regjeringen.no/globalassets/upload/fin/ vedlegg/okstyring/rundskriv/faste/r_109_2014.pdf (accessed 22 December 2020).

Finansministeret, 2017. Vejledning i samfundsøkonomiske konsekvensvurderinger. https://fm.dk/udgivelser/2017/august/vejledning-i-samfundsoekonomiske-konsekvensvurderinger/ (accessed 22 December 2020).

Finansministeret, 2018. Den samfundsøkonomiske diskonteringsrente. https://fm.dk/media/10174/dokumentationsnotat__-den-samfundsoekonomiske-diskonteringsrente.pdf (accessed 22 December 2020).

Finansministeriet, 2019. Dokumentationsnotat om opgørelse af nettoafgiftsfaktoren. https:// fm.dk/media/18103/dokumentationsnotat_om_opgoerelse_af_nettoafgiftsfaktoren_a. pdf (accessed 21 January 2021).

Fosgerau, M., \& Pilegaard, N. (2015). Nettoafgiftsfaktoren. DTU Transport, Vol.. 14. https:// orbit.dtu.dk/en/publications/nettoafgiftsfaktoren (accessed 22 December 2020).

Fraunhofer, 2018. Comparison of technology cost assumptions from MESSAGE and GCAM. https://www.unece.org/fileadmin/DAM/energy/se/pp/CSE/PATHWAYS/2018/PSE prem.model.policy_ws_25.Sept.2018/7_Fraunhofer_Nils.Kemen_TechnologyPortfolio. pdf (accessed 21 January 2021).

Freeman, M., Groom, B., \& Spackman, M. (2018). Social discount rates for cost-benefit analysis: a report for HM Treasury. In A summary report from two workshops on recent advances in social discounting practice and theory.

Gollier, C. (2014). Discounting and growth. American Economic Review, 104(5), 534-37.

Gollier, C., \& Weitzman, M. L. (2010). How should the distant future be discounted when discount rates are uncertain?. Economics Letters, 107(3), 350-353.

Greenstone, M., Kopits, E., \& Wolverton, A. (2013). Developing a social cost of carbon for US regulatory analysis: A methodology and interpretation. Review of Environmental Economics and Policy, 7(1), 23-46.

Groom, B., \& Hepburn, C. (2017). Looking back at social discount rates: The influence of papers, presentations and personalities on policy. Review of Environmental Economics and Policy, 11, 336-356.
Hänsel, M. C., Drupp, M. A., Johansson, D. J., Nesje, F., Azar, C., Freeman, M. C., ... \& Sterner, T. (2020). Climate economics support for the UN climate targets. Nature Climate Change, 10(8), 781-789.

Hirth, L., \& Steckel, J. C. (2016). The role of capital costs in decarbonizing the electricity sector. Environmental Research Letters, 11(11), 114010.

International Energy Agency, 2020. World Energy Model. https://iea.blob.core.windows.net/ assets/fa87681d-73bd-4719-b1e5-69670512b614/WEM_Documentation_WEO2020. pdf (accessed 22 December 2020).

Joint Global Change Research Institute, 2020. GCAM Documentation. http://jgcri.github. io/gcam-doc/v4.2/overview.html (accessed 21 January 2021).

Kommune Kredit, 2020. Takstberegninger. https://www.kommunekredit.dk/laan/vejledninger/fastsaettelse-af-rente-til-brug-for-takstberegninger/ (accessed 21 January 2021).

Miljø -og Energiplanlægningen, 2015. Notat: Strategi for fossilfri varmeproduktion. https:// www.aalborg.dk/media/6779884/strategi-for-fossilfri-varmeproduktion.pdf (accessed 21 January 2021).

Nasa, 2019. The Atmosphere: Getting a Handle on Carbon Dioxide. https://climate. nasa.gov/news/2915/the-atmosphere-getting-a-handle-on-carbon-dioxide/\#:-:tex$\mathrm{t}=$ Once $\% 20 \mathrm{it}$ 's $\% 20$ added $\% 20$ to $\% 20$ the, timescale $\% 20$ of $\% 20$ many $\% 20$ human $\% 20$ lives (accessed 21 January 2021).

National Center for Miljø og Energi, 2018. Miljøøkonomiske beregningspriser for emissioner. https://mfvm.dk/fileadmin/user_upload/MFVM/Miljoeoekonomiske_beregningspriser_for_emissioner.pdf (accessed 21 January 2021).

Nationalt Center for Miljø og Energi, 2019. Miljøøkonomiske beregningspriser for emissioner. https://dce.au.dk/fileadmin/dce.au.dk/Udgivelser/Notater_2019/Miljoeoekonomiske_beregningspriser_for_emissioner.pdf (accessed 21 January 2021).

Nesje, F., \& Lund, D. (2018). Risikojustering av kalkulasjonsrenta i samfunnsøkonomiske analysar. Samfunnsøkonomen, 2018(4), 34-42.

NOU, 2012. Samfunnsøkonomiske analyser. NOU 2012: 16. https://www.regjeringen.no/ no/dokumenter/nou-2012-16/id700821/ (accessed 22 December 2020).

Nordhaus, W. D. (2007). A review of the Stern Review on the Economics of Climate Change. Journal of economic literature, 45(3), 686-702.

OECD, 2018. Cost-benefit Analysis and the Environment: Further Developments and Policy Use. https://www.oecd.org/governance/cost-benefit-analysis-and-the-environment-9789264085169-en.htm (accessed 22 December 2020).

Pacific Northwest National Laboratory, 2018. Overview of the Global Change Assessment Model (GCAM). https://www.unece.org/fileadmin/DAM/energy/se/pdfs/CSE/PATH WAYS/2019/ws_Consult_14_15.May.2019/supp_doc/PNNL-GCAM_model.PDF (accessed 21 January 2021)

Pacific Northwest National Laboratory, 2020. Improving the Representation of Investment Decisions in Integrated Assessment Models. https://www.iamconsortium.org/wp-content/uploads/2020/03/Iyer_IMW-IAMC.pdf (accessed 21 January 2021).

Stern, N., \& Stern, N. H. (2007). The Economics of Climate Change: The Stern Review. Cambridge University press.

Stern, N. (2008). The economics of climate change. American Economic Review, 98(2), 1-37. Squire, L., \& Van der Tak, H. G. (1975). Economic analysis of projects. World Bank Publications. Weitzman, M. L. (2001). Gamma Discounting. American Economic Review, 91(1), 260-271.

Weitzman, M. L. (2010). Risk-adjusted Damma discounting. Journal of Environmental Economics and Management, 60(1), 1-13.

Werner, S. (2017). International review of district heating and cooling. Energy, 137, 617-631.

Wiese, F., Bramstoft, R., Koduvere, H., Alonso, A. P., Balyk, O., Kirkerud, J. G., ... \& Ravn, H. (2018). Balmorel open source energy system model. Energy strategy reviews, 20, 26-34. 